\title{
ACADEMICS AND INTELLECTUAL PROPERTY: TREADING THE TIGHTROPE
}

\author{
TOM REID*
}

\begin{abstract}
[Most Australian universities still uphold the tradition that an academic's work is performed for the greater public good, and that it is therefore necessary to donate back at least the copyright in the academic's scholarly work to the academic, so that the work may be freely disseminated. However, faced with tighter and tighter budgets, the same universities are increasingly turning to commercial partnerships to add to their revenue. The intellectual property created by academics in the course of their employment, if commercially exploited, is potentially a valuable source of revenue to the university. As a result, there is the prospect of growing conflict between academics and their universities over copyright ownership, and the erosion of the tradition of academic ownership of copyright in scholarly works.

Simultaneously, the notion that an academic is paid for the whole of his or her time is being eroded by the trend toward sessional teaching. Nevertheless, the recent case Victoria University $\mathrm{v}$ Wilson illustrates that an academic can still owe fiduciary duties to his or her university capable of covering work performed outside the academic's scope of employment.]
\end{abstract}

\footnotetext{
"Lawyer, Allens Arthur Robinson, Melbourne. This article is based on an earlier version submitted for the AIPPI Australia Group Prize 2004. The author gratefully acknowledges the receipt of the Prize, as well as the permission of the AIPPI Australia Group to submit the revised version to the Deakin Law Review. The author is also indebted to the assistance of Richard Hamer, Michael Dowling and Andrew Goatcher. (C) Allens Arthur Robinson 2004.
} 
Knowledge and research findings have become the most important resources, and the key elements, in the new business paradigm for economic development. ${ }^{1}$

\section{- National Principles of Intellectual Property Man- agement for Publicly Funded Research}

If you allow commercial considerations to drive research and development at universities you ignore the fact that most real groundbreaking research is curiosity driven. It's the groundbreaking research that actually does most to alter our quality of life. ${ }^{2}$

- Chris Patten, Chancellor, the University of Oxford

\section{INTRODUCTION}

There is a flourishing trend for Australian universities to exploit the vast combined knowledge of their academics, through the avenue of intellectual property rights, for commercial profit. Academics are increasingly encouraged to be entrepreneurial in their research and to engage with industry in commercial projects. Universities, motivated by the restructuring of Federal Government funding, are looking to alternative sources, such as commercial partnerships, for revenue. Many Australian universities now have their own special purpose corporate vehicles for commercialising university intellectual property, some examples being the Australian National University's ANUTECH, the University of Queensland's Uniquest, and Flinders University's Flinders Technologies. Academics themselves are becoming more involved in the commercialisation process, as the providers of the consulting services that their universities are beginning to offer, and as a result are becoming more and more aware of the commercial potential of their knowledge.

At the same time, however, the increase in sessional academics, as a proportion of the teaching population, is helping to widen the distinction between the body of academics on the one hand, and the entity that is 'the university' on the other. Further, there remains strong support for the traditional view that universities and their academics are engaged together in an enterprise for the public good, and that commercial considerations should be subordinated to this objective. These are

\footnotetext{
${ }^{1}$ The Australian Research Council, The Australian Tertiary Institutions Commercial Companies Association, The Australian Vice-Chancellors' Committee, The Department of Education, Training and Youth Affairs, The Department of Industry, Science and Resources, IP Australia and The National Health and Medical Research Council, National Principles of Intellectual Property Management for Publicly Funded Research, 2001, 2.

${ }^{2}$ Deryck Schreuder, 'Groundbreaking Research is Driven by Curiosity', The Australian Financial Review (Sydney), 17 May 2004, 34.
} 
good reasons for disputes to arise between academics and their universities over the ownership of intellectual property.

What impact will the changing relationships between universities and academics have on intellectual property law as it applies to those relationships? The issues relevant to this questions that are raised in this article are:

(a) how Australian universities themselves approach the management of intellectual property, and how that approach might change in the future;

(b) given that the tradition that academics hold the copyright in their scholarly works continues to enjoy healthy support, whether that tradition should be protected in law from the risk of encroachment by universities looking to profit more and more from intellectual property; and

(c) in light of the recent case Victoria University of Technology $v$ Wilson (the Wilson Case), ${ }^{3}$ the impact that the changing relationship between academics and universities will have on the existence and scope of fiduciary duties owed by the former to the latter.

As this article explains, the default position under common law and statute in Australia is that intellectual property created by an academic in the course of employment will be owned by his or her employer, the university. The default position, though, may be contractually modified, a step which is increasingly being taken by universities. In order to examine the extent to which this option is taken, this article briefly surveys some major Australian universities' intellectual property policies. The survey demonstrates that there is to some extent an awareness on campus of the need to retain notions of academic freedom in the management of intellectual property.

However, the Wilson case has demonstrated that the universities may acquire an interest even in intellectual property created outside the scope of an academic's employment. This article will argue that the changing relationships between academics and their universities, and in particular the recasting of academics as 'consultants', will make circumstances in which an academic can be said to be in a fiduciary relationship with his or her university increasingly rare. Further, even where a fiduciary relationship exists, the changes being wrought will make it less likely that a commercial opportunity exploited by an academic outside the course of his or her employment could reasonably be said to have been lost to the university, and hence that the academic will owe any fiduciary duty in relation to that opportunity.

\footnotetext{
${ }^{3}$ Victoria University of Technology $v$ Wilson [2004] VSC 33.
} 


\section{MAJOR AUSTRALIAN UnIVERSITIES' Intellectual Property Policies}

Under Australian law the ownership of intellectual property created by an employee in the course of employment vests with his or her employer. For copyright, ${ }^{4}$ designs, plant varieties and circuit layouts this is prescribed by the relevant statute, ${ }^{5}$ whereas for patents the position is provided by the common law. ${ }^{6}$

For academics, as for any other type of employee, the fact that the intellectual property has been created on the instructions of the employer, during working hours, and using the materials and resources of the employer, will indicate that the intellectual property has been created in the course of employment. Conversely, where the academic is not actually an employee of a university, but is instead, for example, a freelance speaker or specially invited presenter, the academic is properly viewed as a 'contractor for services', and the presumption that the university owns the intellectual property created by the academic in performing those services does not apply.

The default position under common law and statute outlined above may be modified by the university's intellectual property policy, granting all or some of the intellectual property rights back to the academic. ${ }^{7}$ The following table gives a flavour of the intellectual property policies applying at some of the major Australian universities, as they relate specifically to the question of ownership.

\footnotetext{
${ }^{4}$ For the purposes of this article the reservation of moral rights under Part IX of the Copyright Act 1968 (Cth) is not discussed.

${ }^{5}$ Copyright Act 1968 (Cth) s 35(6); Designs Act 2003 (Cth) s 13(1)(b); Plant Breeders' Rights Act 1994 (Cth) s 3(1); Circuit Layouts Act 1989 (Cth) s 16(2).

${ }^{6}$ Worthington Pump Engine Co v Moore (1903) 20 RPC 41; Triplex Safety Glass Co v Scorah [1938] 1 Ch 211; Patchett $v$ Stirling Engineering Co Ltd (1955) 72 RPC 50; Spencer Industries Pty Ltd $v$ Collins \& Anor (2003) 58 IPR 425.

${ }^{7}$ The enforceability of an intellectual property policy, of course, depends on express incorporation (usually by reference) in the academic's employment contract.
} 


\begin{tabular}{|l|l|}
\hline \multicolumn{1}{|c|}{ University } & \multicolumn{1}{c|}{ Policy } \\
\hline $\begin{array}{l}\text { Australian National } \\
\text { University }\end{array}$ & $\begin{array}{l}\text { University owns all intellectual property except copyright in works created } \\
\text { by academics 'with the primary intention of it being used for teaching a } \\
\text { course or to demonstrate their research and study activities'. }\end{array}$ \\
\hline Flinders University $^{10}$ & $\begin{array}{l}\text { University owns most intellectual property, but recognises 'principle that } \\
\text { scholarly work should be made available in the public domain to advance } \\
\text { knowledge and benefit the community'.11 }\end{array}$ \\
\hline Monash University ${ }^{12}$ & $\begin{array}{l}\text { University owns all intellectual property except copyright in works of } \\
\text { 'scholarship, research, artistic expression, creativity, or academic debate', but } \\
\text { not including course materials. }\end{array}$ \\
\hline $\begin{array}{l}\text { University of } \\
\text { Melbourne }\end{array}$ & $\begin{array}{l}\text { University grants back all intellectual property to originator, except for } \\
\text { intellectual property developed under an agreement with a third party. } \\
\text { There are restrictions on the right of the creator to assign the intellectual } \\
\text { property, and the university is entitled to a share of any revenue resulting } \\
\text { from its exploitation. }{ }^{15}\end{array}$ \\
\hline $\begin{array}{l}\text { University of } \\
\text { Queensland }\end{array}$ & $\begin{array}{l}\text { University owns all intellectual property except copyright in 'scholarly } \\
\text { works', which includes works based on the academic's 'scholarship, learning } \\
\text { or research', but does not include teaching materials. }\end{array}$ \\
\hline $\begin{array}{l}\text { University } \\
\text { of South Australia }{ }^{18}\end{array}$ & $\begin{array}{l}\text { University owns all intellectual property except copyright in 'conventional } \\
\text { scholarly output', examples of which are 'academic publications, journal } \\
\text { articles, presentation, papers, paintings, books and other creative works', but } \\
\text { which does not include course materials. }\end{array}$ \\
\hline
\end{tabular}

\footnotetext{
${ }^{8}$ Australian National University, Intellectual Property: Ownership, Protection and Commercialisation, $<$ http://info.anu.edu.au/policies/Policies/Legal/Other/Intellectual_Property_Ownership_Protection_and_ Commercialisation.asp> (visited 3 June 2004).

${ }^{9}$ Ibid Clause 4.2.1.

${ }^{10}$ Flinders University, Intellectual Property Policy,

<http://www.flinders.edu.au/ppmanual/policySecretariat/ip.htm> (visited 3 June 2004).

${ }^{11}$ Ibid, Clause 2.3.

${ }^{12}$ Monash University, Intellectual Property Framework,

<http://www.adm.monash.edu.au/unisec/pol/acad21.html>; Monash University Calendar - Statutes,

Chapter 11 (Trust and other property),

<http:www.monash.edu.au/pubs/calendar/statutes/statutes11.htm>; and Monash University Calendar Regulations: Intellectual Property Regulations,

<http://www.monash.edu.au/pubs/calendar/regulations/regulations22.html >(all visited 3 June 2004).

${ }^{13}$ Monash University, Monash University Calendar - Statutes, Chapter 11 (Trust and other property),

above n 16, Clause 2.5 and Monash University, Monash University Calendar - Regulations, Intellectual

Property Regulations, above n 16, Clause 2.1.

${ }^{14}$ University of Melbourne, Intellectual Property Policy,

$<$ http://www.unimelb.edu.au/admindiv/IPPolicy)>; Statute 14,

<http://www.unimelb.edu.au/ExecServ/Statutes/s141.htm> (both visited 3 June 2004).

${ }^{15}$ University of Melbourne, Statute 14, above n 18, Clauses 14.1.3 and 14.1.5.

${ }^{16}$ University of Queensland, Intellectual Property Policy for Staff, Students and Visitors,

<http:www.uq.edu.au/hupp/contents/view.asp?s1=4\&s2=15\&s3=1> (visited 3 June 2004).

${ }^{17}$ Ibid, Clause 5.3.

${ }^{18}$ University of South Australia, University Activities - Intellectual Property: Ownership and Commer-

cialisation Guidelines, <http://www.unisa.edu.au/adminfo/codes/intellectual_property.doc> (visited

3 June 2004).

${ }^{19}$ Ibid, Clause 3.1, definition of 'Conventional Scholarly Output' and Clause 4.1.
} 


\begin{tabular}{|l|l|}
\hline \multicolumn{1}{|c|}{ University } & \multicolumn{1}{c|}{ Policy } \\
\hline University of Sydney $^{20}$ & $\begin{array}{l}\text { University owns all intellectual property except copyright in any journal } \\
\text { articles, conference papers, creative works or proceedings or texts. }\end{array}$ \\
\hline University of Tasmania $^{22}$ & $\begin{array}{l}\text { University owns all intellectual property except copyright in 'scholarly } \\
\text { works', which is defined as having its 'natural meaning and includes for } \\
\text { example: scholarly books, chapters of books, journal articles, conference } \\
\text { papers, textbooks, artistic works or other academic works', but does not } \\
\text { include course materials. }\end{array}$ \\
\hline $\begin{array}{l}\text { University of } \\
\text { Western Australia }\end{array}$ & $\begin{array}{l}\text { Academic owns all copyright (except in computer programs). University } \\
\text { owns all other intellectual property. }\end{array}$ \\
\hline
\end{tabular}

As is apparent from this survey, most universities grant back to their academics the copyright in 'scholarly works' (or similar), reserving a licence over such copyright, and ownership of the remaining intellectual property rights, for themselves. ${ }^{26}$ There are two principal reasons for making such a grant.

The first is simply the commercial reality of staffing: the granting back of intellectual property rights to academics serves to give the university concerned a competitive advantage when trying to attract high quality academics. ${ }^{27}$ An academic's reputation in his or her field comes largely from his or her publications, so the ability to publish, rework and generally deal with works freely, without needing the university's permission, will clearly be an attractive feature of an academic position. Additionally, where there is a profit to be made from the commercial exploitation of intellectual property created by an academic, the academic's ability to share in that

\footnotetext{
${ }^{20}$ University of Sydney, Intellectual Property Rule - A Guide, and Intellectual Property Rule, both at $<$ http://www.usyd.edu.au/policy> (visited 3 June 2004).

${ }^{21}$ University of Sydney, Intellectual Property Rule, above n 24, Clause 4(1).

${ }^{22}$ University of Tasmania, Intellectual Property Policy,

<http://www.admin.utas.edu.au/HANDBOOKS/UTASHANDBOOKS/RULES/POLINT.html> (visited

3 June 2004).

${ }^{23}$ Ibid Clauses 2.4 and 3.1.1.

${ }^{24}$ University of Western Australia, Intellectual Property Policy,

$<$ http://www.research.uwa.edu.au/policies/welcome/policies/ip_policy>; Intellectual Property Regulations, <http://www.research.uwa.edu.au/policies/welcome/policies/ip_policy/regulations> (both visited 3 June 2004).

${ }^{25}$ University of Western Australia, Intellectual Property Regulations, above n 26, subregulations 4(1) and 4(4).

${ }^{26}$ The exception is the University of Melbourne, which adopted its more liberal intellectual property policy in 1999 (although the amendment was controversial and did not finally come into effect until October 2003). The stated intention of its policy is to encourage 'an entrepreneurial and pro-active approach among academics through increasing the rewards to them or their own work'. Given this intention, it therefore seems inconsistent that Melbourne University Private, the University of Melbourne's commercially-oriented vocational training arm (which presumably is even more keen to encourage entrepreneurial academics), has a policy similar to the other universities tabulated above, restricting academics to owning only copyright in 'scholarly publications'. This policy is said to reflect 'the need to balance the commercial objectives of our clients and our own businesses with the responsibility as a university to disseminate new knowledge': see Melbourne University Private, Intellectual Property Policy, <http://mupl-www1.muprivate.edu.au/index.php?id=13> (visited 3 June 2004), section F(ii).

${ }^{27}$ Samuel Ricketson, 'Universities and their Exploitation of Intellectual Property' (1996) 8 Bond Law Review 32, 42-3.
} 
profit will obviously be a further attractive feature to him or her. Naturally, the university's own reputation also benefits from the enhanced reputation of its academics.

The second (and more intangible) reason is the traditional view that the role of academics is primarily oriented toward learning and discovery for the public good, not for commercial profit. The free handling and dissemination of knowledge is obviously important to fulfilling such a role. It has been said, therefore, that an academic's work should not be interfered with by intellectual property laws that are fundamentally oriented toward protecting monopolies. ${ }^{28}$ A recent study shows that academics consider the right to the unhindered publication of their work to be more important than commercial considerations, even where those commercial considerations would include financial rewards to the academics personally. ${ }^{29}$ In other words, academics themselves still see the principal benefit of owning the intellectual property in their research and materials as being the ability to publish, rather than to profit.

To the extent that the second of the reasons above is informed by the nebulous concept of a 'right to free speech', its relevance may be questioned in Australia where, unlike in the United States, there is no such absolute right. ${ }^{30}$ In the United States, there was (and arguably still is) a common law 'teacher exception', under which the presumption of employer ownership with respect to the copyright in an academic's scholarly works is reversed, granting default ownership of the copyright to the academic. ${ }^{31}$ This is said to have been 'the academic tradition since copyright law began'. ${ }^{32}$ Although it is not expressed in so many words, the right to free speech contained in the American Bill of Rights, or at least the sentiment of it, does seem to underlie the discussion in some recent American cases of the 'teacher exception'. In fact, the paucity of American case law that supports the existence of the 'teacher exception' is said to be evidence not that the rule is unjustified, but that the concept of academic independence is so strongly held that the 'teacher exception' is rarely challenged. ${ }^{33}$

\footnotetext{
${ }^{28}$ See Patricia Loughlan, 'Of Patents and Professors: Intellectual Property, Research Workers and Universities' [1996] 6 European Intellectual Property Review 345; contra Stephen Crespi, 'Intellectual Property and the Academic Community' [1997] 1 European Intellectual Property Review 6; also A L Monotti, 'University Copyright in the Digital Age: Balancing and Exploiting the Rights in Computer Programs, Web-based Materials, Databases and Multimedia in Australian Universities' [2002] 5 European Intellectual Property Review 251; A L Monotti, 'Allocating the Rights in Intellectual Property in Australian Universities: An Overview of Current Practices' (1999) 27 Federal Law Review 421; A L Monotti, 'Who Owns My Research and Teaching Materials - My University or Me?' (1997) 19 Sydney Law Review 425.

${ }^{29}$ A L Monotti, 'Allocating the Rights in Intellectual Property in Australian Universities: An Overview of Current Practices', above n 11, 441-3.

${ }^{30}$ Lange v Australian Broadcasting Corporation (1997) 189 CLR 520; Nationwide News Pty Ltd v Wills (1992) 177 CLR 1.

${ }^{31}$ See Hays and MacDonald $v$ Sony Corporation of America 847 F.2d 412 at 416-17; Weinstein v University of Illinois 811 F.2d 1091, 1094.

${ }^{32}$ Weinstein v University of Illinois 811 F.2d 1091, 1094.

${ }^{33}$ Hays and MacDonald $v$ Sony Corporation of America 847 F.2d 412, 417.
} 
The purpose of this article is not to discuss the merits or otherwise of the concepts of free speech and academic independence as they apply in Australia. Nevertheless, as the above survey shows, the notion that an academic should hold at least the copyright in his or her scholarly works is a very strongly held one, as shown by its incorporation in many universities' intellectual property policies. Continuing support for the 'public good' aspect of academics' work is apparent; in fact, most of the above universities' intellectual property policies contain statements expressly recognising this. For example, the University of Sydney's guide to its intellectual property policy states:

Universities are places of scholarship and research, and those who work in a university value excellence in teaching and research, and assume responsibility for the acquisition, generation and dissemination of knowledge. Intrinsic to this process is the need to have open channels of communication and to be able to engage in discussion freely and without inhibition. $^{34}$

The question then becomes whether, on the assumption that that notion is worth protecting, is it sufficiently protected by these policies, or whether some further protection is needed under intellectual property law. A university intellectual property policy is vulnerable to amendment at any time and, as the pressure on universities to commercialise their intellectual property intensifies, there is an inherent risk that academics' scholarly works will be targeted as potentially profitmaking intellectual property.

If traditions of academic freedom are worth protecting, is there, then, a case for a general exception at law to the presumption of employer ownership of intellectual property, for 'scholarly works'? There is a precedent in Australian law for applying special treatment to a particular class of employees in respect of intellectual property created by them: s 35(4) of the Copyright Act 1968 (Cth) provides that (subject to agreement between the parties), a journalist retains certain copyrights in works produced for publication in a newspaper or similar medium. The origins of this exception are the historical convention that copyright in a journalist's work remained with the journalist for the purposes of the copying of it (particularly by press-cutting services), or for reproducing it in a book.

Certainly, there are difficulties in determining what constitutes a 'scholarly work'. As it becomes part of the academic's scope of employment to take on commercial consulting work, the line between 'scholarly' and 'non-scholarly' works will be blurred. Journal articles, conference papers, textbooks and so forth clearly qualify as scholarly works, and in some cases are specifically defined as such in intellectual property policies and statutes. But for the purpose of determining the ownership of valuable intellectual property rights, a reference such as the University of Tasma-

\footnotetext{
${ }^{34}$ University of Sydney, Intellectual Property Rule - A Guide, above n 19.
} 
nia's, to the term 'scholarly works' as having its 'natural meaning', is obviously imprecise.

Of course, a 'one size fits all' statutory definition of 'scholarly works' would be difficult. The notion of scholarship is difficult to construe at Melbourne University Private for example, which considers itself 'a client-focussed intellectual environment in which original work and new knowledge is often developed in response to client needs, and in the context of specific contracts'; ${ }^{35}$ in this environment it is questionable whether any scholarship, in the traditional sense of the word, is conducted at all. On the other hand, the benefit of a statutory definition is that its interpretation in subsequent case law would gradually reduce the ambiguity of the term. The current situation is that each university's intellectual property statutes contain a different variations such as 'scholarly works', 'scholarly publications', 'conventional scholarly output' and so on; in so far as these terms form part of an academic's employment contract, their meaning must be construed in the context of that contract. This means that a court decision interpreting the use of one term in one university's policy is of little value as precedent in interpreting the way a different university uses a similar term.

Certainly, there is merit in the argument that it is for each university to define, for itself, notions of scholarship. But the risk is that, as financial pressures increase, the motivation for universities to take intellectual property for themselves will become stronger, and the protection to academics' rights over their scholarly works, currently volunteered by universities, will be gradually eroded. A statutory exception to the presumption of employer ownership of intellectual property rights in the case of scholarly works may be a suitable avenue to prevent this.

\section{ACADEMICS AS FIDUCIARIES}

Quite apart from the 'course of employment' test for ownership of intellectual property, universities have begun using the fiduciary mechanism as a tool to protect their interests in intellectual property. The best Australian example of this is the recent decision of Nettle $\mathbf{J}$ of the Supreme Court of Victoria in Victoria University of Technology $v$ Wilson, which is currently on appeal to the Full Court. ${ }^{36}$ To understand the nature of the fiduciary duty involved, it is necessary first to set out the circumstances in which it was found to exist.

In 1999 two academics at the Victoria University of Technology (VUT) were approached by a commercial third party in relation to the development of online teaching content. The two academics in question were Professor Wilson, who was head of VUT's School of Applied Economics and a professor in its Faculty of Business and Law, and Dr Feaver, a senior lecturer in the School of Applied Eco-

\footnotetext{
${ }^{35}$ Melbourne University Private, Intellectual Property Policy, above n 31, section B(ii).

${ }^{36}$ Victoria University of Technology $v$ Wilson [2004] VSC 33.
} 
nomics and the Head of the School's Centre for International Business Research and Education (CIBRE). CIBRE had been established to commercialise the knowledge of the School of Applied Economics, and was designed to sell online teaching content for profit to the university. This online teaching content was similar to that wanted by the commercial third party, and which the two academics were approached to develop for it.

As the project developed, it expanded such that the two academics began working on the design of the software and system architecture needed to deliver the teaching content. Although neither had any experience in software programming, Dr Feaver taught himself the necessary skills while Professor Wilson supervised the overall design of the invention. During this period, having realised the value of the intellectual property they were creating, they signed a memorandum of understanding under which they agreed to share that intellectual property between themselves. However, at various points both before and after the signing of the memorandum, the academics used the logos of both VUT and CIBRE in relation to them.

VUT was only partially successful in arguing that the work of Professor Wilson and Dr Feaver was within the scope of their employment by the university. The 'paradoxical $^{37}$ reason for this was that Professor Wilson's position was sufficiently senior such that, when he signed the memorandum dividing ownership of the relevant intellectual property between himself and Dr Feaver, he was effectively acting on behalf of the university. Therefore, after the memorandum was signed, the university had, in effect, agreed that work carried out after that point would not be within the scope of the two academics' employment. ${ }^{38}$

However, the university was able to claim a beneficial interest in the work carried out after the date of the memorandum through Justice Nettle's finding that Professor Wilson and Dr Feaver, as professional employees, owed fiduciary obligations to the university. These obligations had been breached when the two academics diverted away from the university the opportunity to develop the invention and the software itself. The two academics therefore held the intellectual property developed after the date of the memorandum on trust for VUT.

The Wilson case illustrates the key difference in focus between the 'course of employment' test for ownership of intellectual property on the one hand, and the fiduciary obligations of professional employees on the other. The difference is this: where the 'course of employment' test is primarily focused on the scope of the terms of employment of the employee, the fiduciary duty is more concerned with the loss of the opportunity to the employer. Practically, the existence of a wide fiduciary obligation on the part of a professional employee may operate to widen the ambit of what, under common law and statute, is considered to be the intellectual property of the employer (provided, of course, that the university has not consented to the academic's appropriation of the opportunity).

\footnotetext{
${ }_{38}^{37}$ Victoria University of Technology $v$ Wilson [2004] VSC 33, [64].

${ }^{38}$ Ibid.
} 
How appropriate is this result in the academic context, where universities are increasingly being run as a business, replete with 'vision' and 'mission' statements, and academics are being recast as 'consultants'? Although the characterisation of the employee-employer relationship as a fiduciary one (in some circumstances) is by no means new, ${ }^{39}$ how broad should the scope of the resulting fiduciary obligations be in the context of university academics? To what extent should the changing nature of that relationship, which (as discussed above) is traditionally viewed as an enterprise engaged in for the public good, be taken into account?

\section{A A Rock and a Hard Place}

In the Wilson case, Nettle $\mathrm{J}$ said that:

Perhaps it is not all that long ago that professional public servants (in the broad sense that includes academics) were expected to refrain from private money making activities. The theory then was that such persons were appointed to do a job which was expected to be all consuming, and they were paid a salary in effect for the whole of their time. ${ }^{40}$

As a side issue, this statement is not entirely true - academics have been writing and publishing books, and receiving the royalties, for many years. However, whatever the historical situation, it is certainly true that nowadays even tenure is not sufficient to require university academics to devote all of their time to the performance of work for the university. Indeed, VUT's policy expressly provided that its academics were free to perform non-university work (that is, work outside the course of their employment), so long as this was done outside university hours and did not conflict with the academic's university duties. ${ }^{41}$ Many universities, in fact, actively encourage their academics to take on outside work, in order to develop and maintain industry links for sponsorship and investment, and to keep the academic up to date with happenings in his or her field. For example, Goal Five of the seven stated goals in the University of Sydney Strategic Plan 1999-2004 is to engage with industry and the professions; some of its strategies for doing so are to:

maximise the University's contribution to the community through the involvement of its staff in professional associations, government agencies and professional regulatory bodies. ${ }^{42}$

and to:

\footnotetext{
${ }^{39}$ See, for example, New Zealand Netherlands Society 'Oranje' Incorporated $v$ Kuys [1973] 2 All ER 1222, 1225 (Lord Wilberforce); Consul Development Pty Ltd v DPC Estates Pty Ltd (1975) 132 CLR 373, 377 (McTiernan J) (dissenting); Hospital Products Ltd v United States Surgical Corporation (1984) 156 CLR 41, 141 (Dawson J).

${ }^{40}$ Victoria University of Technology $v$ Wilson [2004] VSC 33, [67].

${ }^{41}$ Victoria University of Technology $v$ Wilson [2004] VSC 33, [68].

${ }^{42}$ The University of Sydney, Strategic Plan 1999-2004,

<http://www.usyd.edu.au/about/publication/pub/strategic.shtml> (visited 3 June 2004) 23.
} 
recognise professional service in the criteria for promotion of academic staff. ${ }^{43}$

The encouragement of non-university work by academics, as part of an overall strategy to improve the commercialisation of intellectual property by universities, is also supported at the government level. A 2002 Victorian State Government report identifies industry consulting work by university academics as 'an important and valuable means of developing networks and "commercial savvy"', and encourages universities to offer their academics flexible employment conditions to allow this to occur. $^{44}$

The push for academics to take on work outside the course of their employment, then is clear. But equally clear is that the scope of what an academic is expected to do within the course of his or her employment is also expanding, beyond the traditional realm of pure scholarship. An Australian Research Council study highlighted the ability of academics to pull in government grants and private sector funding as 'becoming a significant factor in academic career advancement'. ${ }^{45}$ Income from university consultancies and contract research has, in the last few years, formed between $4 \%$ and $5 \%$ of income to higher education institutions, so universities clearly have a more than negligible economic interest in encouraging their academics to perform more of this kind of work. ${ }^{46}$

The discussion above is intended to illustrate the fact that, simultaneously, universities are placing increasing importance on making money from the intellectual property created by academics, whereas academics are facing increasing pressure to find work that they can perform in the personal capacity, both in order to advance their careers, and (for sessional academics) to supplement their income. As a result, academics who come across commercial opportunities will be in an increasingly awkward position, uncertain as to whether they will be permitted to take the benefits of those opportunities for themselves, or whether the interest in those benefits is rightfully held by the university.

There is a further complication for academics in determining whether they may take the benefits of a commercial opportunity for themselves: it will very often be difficult to determine whether the academic is approached in relation to the commercial

\footnotetext{
${ }^{43}$ Ibid 24.

44 State Government of Victoria, Department of Innovation, Industry and Regional Development, Managing and Commercialising Intellectual Property: A Guide for Victorian Universities and Research Institutes, 2002, 24.

${ }^{45}$ Australian Research Council, Research in the National Interest: Commercialising University Research in Australia, 2000, 9.

${ }^{46}$ The Commonwealth Department of Education, Science and Training, Finance 2002: Selected Higher Education Statistics, 2003, <http://www.dest.gov.au/highered/statistics/finance/2002/finance2002.pdf> 3; Finance 2001: Selected Higher Education Statistics, 2002,

<http://www.dest.gov.au/highered/statistics/finance/2001/finance 2001 final.pdf> 3; Finance 2000

Selected Higher Education Statistics, 2001 (as revised),

<http://www.dest.gov.au/archive/highered/statistics/finance/2000/Revised_Finance2000.xls>

3 (all visited 3 June 2004).
} 
opportunity in his or her personal capacity, or as a representative of the university. Much of the value of the academic to the commercial partner lies in the academic's professional status. For example, in the case of academics retained as expert witnesses in litigation, the force of the witness's opinion is at least partially derived from his or her status as 'the highly respected Professor X of ABC University'. In the commercial context, an invention resulting from a commercial collaboration might be promoted to investors or customers as the work of 'Professor X' or 'Dr Y'. The status of the academic lends intellectual weight, and therefore economic value, to the intellectual property produced by the commercial collaboration. Therefore, it would be a mistake if equity deemed that any approach made to an academic on the basis of his or her distinguished status to be an opportunity to the university. Such an interpretation would, as a practical consequence, leave virtually no room at all for any academic to legitimately accept an opportunity in his or her personal capacity, which would be wrong given that (as noted above), both universities and governments encourage exactly that. ${ }^{47}$

It is also worth noting that from a policy perspective, it may in fact be prudent for the university not to pursue the beneficial interest in the first place. If the university is to take all of the benefits of the intellectual property resulting from a transaction, there will be less incentive for the academic to perform the work in the first place (since, as in the Wilson case, much of the work is often performed in the academic's spare time). If the work is not performed, not only is the intellectual property lost, but the university also loses the intangible benefits of a 'commercially savvy' academic referred to above. The University of Queensland, for example, appears to recognise this expressly in its intellectual property policy, which assures its staff that the University will not 'seek to claim ownership over any IP created by staff outside the course of their employment'. ${ }^{48}$

\section{B The Application of Equity}

To the extent that private sector consulting-style work is becoming accepted as part of the scope of the academic's employment, the common law/statutory test for ownership of intellectual property, as modified by universities' intellectual property policies, should apply (subject to the suggested statutory exception for 'scholarly works' above). But where, as in the Wilson case, an academic's work is found to be outside the scope of employment, the changing relationship between academics and universities has implications for the application of the rules of equity to the facts of a particular case, in the following ways.

First, though Nettle $\mathbf{J}$ recognised that academics are being increasingly cast as 'contractors', he later relied on Professor Wilson's and Dr Feaver's status as 'professional employees' to support a finding that a fiduciary relationship existed between

\footnotetext{
${ }^{47}$ Nettle J acknowledged this point in Victoria University of Technology v Wilson [2004] VSC 33, [67].

${ }^{48}$ University of Queensland, Intellectual Property Policy for Staff, Students and Visitors, above n 15, Clause 5.2.
} 
them and VUT. ${ }^{49}$ The usefulness of categorising academics as 'professional employees' should be questioned, for example in the case of a sessional appointee (who may be appointed for as little as one semester's worth of teaching). A survey in 2000 by the Department of Education, Science and Training noted that numbers of sessional appointees are increasing in proportion to staff with academic tenure. ${ }^{50}$ In the case of a sessional academic paid, for example, to teach three classes per week (not including preparation time), it is highly unlikely that he or she could be characterised as having undertaken to act in the interests of the university, an undertaking that is often considered a defining element of a fiduciary relationship, ${ }^{51}$ notwithstanding that he or she is a 'professional employee'.

The argument made in this section is not that a fiduciary duty is inappropriate in the academic context, or that academics should be able freely to appropriate commercial opportunities for their own benefit. Rather, the point is that when considering the existence or otherwise of a fiduciary relationship, and the scope of the duties under it, judges need to look beyond the academic's status as a 'professional employee' and consider in detail the nature of his or her relationship with the university. In light of the trend towards 'contractor' academics and the increasing use of sessional appointees, it is submitted that cases where an academic has a fiduciary relationship with his or her university at all will become rarer.

Secondly, where a fiduciary relationship can be said to exist, judges need to take into account the statements and policies of universities that encourage the performance of non-university work when determining the scope of the fiduciary duties owed. As noted above, many universities (including VUT in the Wilson case) expressly or impliedly encourage their academics to develop their knowledge and experience, and to acquire new skills, by taking on a particular type of work outside the course of their employment. ${ }^{52}$

If this is so, it must be asked: is the commercial opportunity in question, which the academic appropriated for him or herself, and which required the academic to work outside the course of his or her employment to exploit, one that was truly available to the university to exploit for itself, or is it one that was made available to the academic in the course of conducting his or her non-university work? The answer is that it will often be difficult to tell and, as with all fiduciary duties, the outcome will depend heavily on the facts of the case.

\footnotetext{
${ }^{49}$ Victoria University of Technology $v$ Wilson [2004] VSC 33, [68]. Note that Nettle J was not using the term 'contractors' to imply that academics are, from a legal perspective, independent contractors instead of employees, but rather to emphasise the increasing conceptual separation between the academic and the university.

${ }^{50}$ Department of Education, Science and Training, Higher Education Division, Characteristics and Performance Indicators of Australian Higher Education Institutions, 2000, 11.

${ }^{51}$ See, for example, Moorgate Tobacco Co Ltd v Philip Morris Ltd [No 2] (1984) 156 CLR 414, 436 (Deane J).

${ }^{52}$ Of course, this is not the same as saying that the university could be argued to have consented to the appropriation of a benefit by the academic where a fiduciary duty would otherwise have been breached. The requirements of disclosure with respect to a defence of informed consent are high and would be unlikely to be satisfied in this kind of situation: see generally Boardman v Phipps [1966] 3 All ER 721.
} 
However, when interpreting these facts, judges must be cognisant of the fact that academics are being encouraged to exploit commercial opportunities, and that an academic exploiting an opportunity, even within his or her field of endeavour, will not necessarily be appropriating an opportunity rightfully belonging to the university.

\section{CONCLUSIONS}

Universities are moving away from their traditional role as centres of academic learning and research, and toward becoming providers of training and on-demand expertise. They are expecting more from their tenured academics with respect to bringing in private sector funds, and thus expanding the scope of intellectual property rights that they can claim were created in the course of the academic's employment. On the other hand, it is becoming more important for academics to take on private sector work in their personal capacity, both to advance their careers and (for sessional appointees at least) to supplement their income. As the body of academics becomes increasingly distinct from the entity that is 'the university', the scope for conflict between the two over the rights to intellectual property (whether held under common law and statute, or in equity) will increase. The purpose of this article has been to highlight some of the legal issues that might arise out of these developments.

First, there is still strong support, as this article's survey of university intellectual property policies shows, for the tradition that the intellectual property in scholarly works should belong to the academic who creates them, and there are good policy reasons behind this tradition. However, the tradition is preserved only in those university policies and is not reflected under the common law or statute, where the general presumption applies that the employer university will own the employee academics' creations made in the course of employment. As such, there is a risk that their increasingly commercial bent will tempt universities to abandon these policies, and to appropriate those scholarly works for profit. An exception similar to the 'journalist exception' under the Copyright Act, granting default ownership of scholarly works to the academic who created them, would avert this risk.

Secondly, the changing relationship has consequences for the application and scope of fiduciary relationships between academics and their universities. Judges must therefore be cautious, when determining whether a fiduciary relationship exists in a particular case, as to whether the academic's status as 'professional employee' in fact reflects the reality of his or her relationship with the university. If a fiduciary relationship does exist, judges must be cognisant of the fact that not every opportunity that is exploited by an academic will be the subject of a fiduciary duty, even where the academic is working within his or her field of endeavour. An academic's salary is no longer awarded in return for the whole of his or her time, and universities are in fact encouraging their academics to participate heavily in activities out- 
side the scope of their employment. Given this, it is submitted that it will become more difficult for a university to argue that a particular opportunity was one that was open to the university to exploit for itself. 